\title{
Reading Psalm 35 in Africa (Yoruba) Perspective
}

\author{
Rev Prof David T. Adamo (University of South Africa)
}

\begin{abstract}
Psalm 35 appears to be one of the scariest Psalms because of the various expressions of hate and the Psalmist invoking wrath and death on his enemies. In the Western context, it is not one of the favourites of the Psalms. However, in a Yoruba context, Psalm 35 is one of the favourites because of its use for purposes of defence, victory, and protection. The purpose of this article is to discuss how Psalm 35 is used in a Yoruba context to meet the peculiar need of Yoruba people against enemies. Although there are similarities and differences between Psalm 35 and Yoruba ofo oro ogede, the similarities actually influence Yoruba Christians and non-Christians to use Psalm 35 like ofo or madarikan, orogede with a firm belief that it contains a more mysterious power from God than the Yoruba ofo, ogede and madarikan. Psalm 35 is, therefore, read, memorized, chanted, sung or inscribed in parchment to express the African faith, and their personal origin from God. Psalm 35 is also read in order to motivate God to perform a miracle as he has done originally with the people of ancient Israel.
\end{abstract}

KEYWORDS: Africa, Hermeneutics, Psalms, Old Testament, Incantation, Psalm 35.

\section{A INTRODUCTION ${ }^{1}$}

Psalm 35 has been given different titles by different commentators. While Kraus titles it "Plea for Yahweh's Assistance against False and Hostile Witnesses," Craigie gives it "A Royal Psalm for International Crisis." ${ }^{2}$ While Weiser titles it, "Lament of one of the Quiet in the Land."3 deClaisse-Walford, Jacobson, and Tanner title it "Fight for Me, Save me." "While Ross titles it "Hated Without a

* Submitted: 08/04/2019; peer-reviewed: 13/05/2019; accepted: 27/09/2019. David Tuesday Adamo, "Reading Psalm 35 in Africa (Yoruba) Perspective," Old Testament Essays 32 no. 3 (2019): 936 - 955. DOI: https://doi.org/10.17159/2312-3621/2019/ v32n $3 \mathrm{a} 9$.

1 This article was presented at the Society of Biblical Literature (SBL) Annual Meeting on Nov 18-21, 2017.

2 Peter C. Craigie, Psalm 1-50, (Waco: Word Books, 1983), 10; Hans-Joachim Kraus, Psalm 1-59 (trans. Hilton Oswald; Minneapolis: Augsburg Publishing House, 1978).

3 Artur Weiser, The Psalms (Philadelphia: The Westminster Press, 1998), 300.

4 Nancy L. deClaisse-Walford, Rolf A. Jacobson, and Beth L. Tanner, Introduction to the Psalms (St. Louis: Chalice Press, 2004), 331. 
Cause." "Mays calls it "You Deliver the Weak." Schaefer titles Psalm 35, "Do not let them Rejoice over Me."7 According to Anderson, the title is "A Prayer for Deliverance." 8 Brueggemann and Bellinger Jr. call Psalm 35 "Psalms of zeal." Oduyoye includes this chapter as one of the "The Psalms of Satan." 10 The above titles by various commentators can be categorised into two: deliverance or assistance and crisis of enemies or persecution. Although the book of Psalms is one of the most loved and read books of the Bible, Psalm 35 is certainly not one of them because it contains words of hate instead of love. This is a complex poem that begins with the images of war. The text is corrupt in many places, the syntax and the metaphors portrayed are difficult to understand. ${ }^{11}$ The structure is also complex and there is no unanimous agreement among scholars as to its division into the stanza. Psalm 35 belongs to the group of the most troublesome parts of the Bible. ${ }^{12}$ The enemies in Psalm 35 are not foreign enemies. ${ }^{13}$ In fact, someone rewrote the book of Psalms and removed all the imprecatory Psalms including Psalm $35 .^{14}$

The purpose of this article is to demonstrate how Psalm 35 is read and understood in Yoruba context and also to demonstrate that most Yoruba Christians seem to be more at home with this Psalm than most Western scholars because of its similarity to their religion and tradition. ${ }^{15}$ Another purpose of this

5 Allen P. Ross, A Commentary on the Psalms: Volume 1 (1-41) (Grand Rapids: Kregel Academic, 2011), 759;

$6 \quad$ James L. Mays, Psalm (Louisville: Knox Press, 2011), 154.

$7 \quad$ Konrad Schaefer, Psalms (Collegeville: The Liturgical Press, 2001), 86.

8 Albert A. Anderson, The Book of Psalms, (London: Marshall, Morgan and Scott, 1972), 275.

9 Walter Brueggemann and William H. Bellinger Jr., Psalms (Cambridge: Cambridge University Press, 2014), 176.

10 Modupe Oduyoye, Psalms without the Curse Words (Ibadan: Sefer Press, 1997), 7-10.

11 deClaisse-Walford, Jacobson and Tanner, The Book of Psalms, 331.

12 David T. Adamo, "The Imprecatory Psalms in African Context," in Biblical Interpretation in African Perspective, (ed. D. T. Adamo; Lanham: University of America, 2006), 139-153. There are about ninety eight verses in 32 chapters of the Bible and about 94 words describing enemies. The following are widely recognized as imprecatory Psalms: 5:10, 6:10; 7:6,7, 15-16; 9:19-20; 10:15; 17:13; 28:3; 31:17;-18; $35 ; 40: 14-15 ; 52: 5 ; 54: 5 ; 55: 9,56: 7 ; 58: 6-10 ; 59: 5,11-13 ; 68: 1-2,30 ; 69: 22-25,27-$ 28; 70:2-3; 71:13; 74:11-, 22-23;; 79:6, 10,13;83:9;,11,,13-18;; 94:1-2; 104:35; 109:615, 17-20, 29;:5-8; 137:7-9;; 139:19, 21-22;; 140:8-11; 141:10;143:12

13 Ross believes that the enemies are foreign, (Ross, Commentary on the Psalms, 763).

14 Oduyoye, Psalms without the Curse Words. 7-10

15 See more details about what African Biblical Hermeneutics means in David T. Adamo, "The Task and Distinctiveness of African Biblical Hermeneutic(s)," Old Testament Essays, 28/1 (2015): 31-52; "What is African Biblical Hermeneutics?" 
article is also for readers/scholars to understand not only the resemblance of both Psalm 35 and African ogede, ofo, ormadarikan in content, intention, and formula, but in order to understand why Psalm 35 is loved by Yoruba and other African Christians, especially when they are in trouble. ${ }^{16}$

Although references will also be made to many other methodologies, such as the historical critical method and narrative criticism, African Biblical Hermeneutics which I consider Africentric ${ }^{17}$, will be used. ${ }^{18}$ Less I am misunderstood, this article is not to prove that Africentric or African Biblical Hermeneutics approach is better than the Western approach. ${ }^{19}$ Both can be complementary.

\section{B WESTERN CONTEMPORARY LITERARY ANALYSIS OF PSALM 35.}

Since the Western contemporary type of literary and exegetical analysis forms the background to the Africentric approach for the study of Psalms in general, it is important to discuss the Western literary approach to Psalm 35 first.

Journal of Black Theology, 13/1 (2015): 59-72; Knut Holter, Contextualized Old Testament Scholarship in Africa (Nairobi: Acton Publisher, 2008); Interpreting Classical Religious Texts in Contemporary Africa,(Nairobi: Acton Press, 2007); Mary N. Getui, Knut Holter, and Victor Zinkuratire (eds.), Interpreting the Old Testament in Africa (New York: Peter Lang, 2001).

16 Africentric approach is also used outside the African continent. It has been confirmed that it is not only the Yoruba Christians who love Psalm 35 and used it. Almost all the missionary churches use Psalm 35 in Africentric way. See also L. E. Ugwueye and E.N. Uzuegbunam, "An Appraisal of the Use of Psalm 35 as 'Dangerous Prayer' in Mountain of Fire and Miracle (MFM) Church," African Research Review 7/1 (2012): 14-33.

17 African spelling is Afri-ca and not Afro-ca. For this reason, I prefer Africentric instead of Afrocentric.

18 African Biblical hermeneutic is both a methodology and hermeneutics that uses mainly African culture to interpret the Bible. It is an interpretation that makes "African social-cultural context a subject of interpretation." It is "the re-reading of the scripture from a premeditatedly Africentric perspective." I prefer the word Africentric to Afrocentric simply because the continent is Afri-ca and not Afro-ca. David T. Adamo, "The Task and Distinctiveness," 31-52; "What is African Biblical Hermeneutics?" 5972.

19 There is no one hundred percent objectivity. No interpretation that is absolute without bias. The reason is that there is no individual interpreter who is completely detached from his or her environment or experience and culture. David T. Adamo, "Reading Psalm 109 in African Christianity," Old Testament Essays 21/3 (2008): 575592. 
Though Psalm 35 is believed to be Davidic, it appears that the composition should be later probably in the post-exilic period. ${ }^{20}$ Since Psalm 35 belongs to the group of Psalms called "imprecatory psalm," it is important to discuss briefly the opinion of major Western scholars who belong to the Western interpretative tradition. Imprecatory Psalms are Psalms which contain a cry for divine vengeance and request God to revenge against the Psalmists" enemies. They want immediate judgment against the wicked ones. ${ }^{21}$ There is still a debate whether the term "imprecatory Psalms" is appropriate or inappropriate. While some scholars believe that it is appropriate, ${ }^{22}$ others think that it is inappropriate. ${ }^{23}$ The problems associated with the imprecatory Psalms are not limited to the acceptance of its terminology alone. For example:

1 they are full of curses, vengeance, and violence and that is why they have been labelled as Psalm of hates, vengeance, violence.24 According to Crenshaw, prayer for vengeance cannot be justified theologically no matter what. 25

2 they are called Psalms of disorientation and darkness according to $\mathrm{W}$ Brueggemann; ${ }^{26}$

3 they contradict the teaching of the New Testament which encourages us to love our enemies, and therefore the imprecatory Psalms reflect a lower standard of ethics than that of the New Testament; ${ }^{27}$ Lancey also holds

20 Ross, Commentary on the Psalms, 763.

21 David Simango and Paul Kruger, "An Overview of the Study of Imprecatory Psalms: Reformed and Evangelical Approaches to the Interpretation of Imprecatory Psalms," Old Testament Essays 29/3 (2016): 581-600. Doi: http://doi.org /10.17159/2312-3621/2016/v29n3a13.

22 J. Carl Laney, "A Fresh Look at the imprecatory Psalms," Bibliotheca Sacra 138 (1981): 35-44; John N. Day, "The Imprecatory Psalms and Christian Ethics," Bibliotheca Sacra 159 2002): 166-185; Cyril Okorocha, "Psalms," in Africa Bible Commentary (ed. Tokunbo Adeyemo; Nairobi: Word Alive Publishers, 2006), 605-746.

23 Chalmers Martins, "Imprecatory in the Psalms," in Classical Evangelical Essays in Old Testament Interpretation, (ed. W. Kaiser; Grand Rapids: Baker, 1972), 113; Hendricks Peels, Shadow Sides: the Revelation of God in the Old Testament (Carlisle: Paternoster, 2003), 90; Ernst R. Wendland, Analyzing the Psalms (Dallas: Institute of Linguistics, 1998), 48; Erich Zenger, A God of Vengeance? Understanding the Psalm of Divine Wrath (trans. Linda Maloney; Louisville: Westminster John Knox Press, 1996), viii.

24 James L. Crenshaw, The Psalms: An Introduction (Grand Rapids: Eerdmans Publishing Company, 2001), 65.

25 Crenshaw, The Psalms, 68

26 Walter Brueggemann, The Message of Psalms (Minneapolis: Augsburg Publishing House, 1984), 52.

27 Zenger, God of Vengeance, 1996. 
the opinion that it is not good for Christian to pray the imprecatory Psalms. ${ }^{28}$

4 that they are merely a linguistic style or an ordinary literary device which the author may not take very seriously. ${ }^{29}$

Many Western biblical scholars have proposed some solutions in their interpretations of imprecatory Psalms. There is a belief that the words of the Psalmists are personal sentiments and should not be treated as inspired words of God but a personal response of men who were aggrieved, hurt, oppressed and persecuted thought of revenge. ${ }^{30}$ It is a response to God's revelation. ${ }^{31}$ Scholars believe that all the words of vengeance, violence, and hate are words of prophecy in the Old Testament and that does not belong to the personal wish of the Psalmist to see destruction happen to their enemies. In other words, these are prophetic pronouncements or predictions judgment and not the personal sentiment of the Psalmist. ${ }^{32}$

Laney sees the curses in the imprecatory Psalms as covenant curses because they have covenant as their basis. ${ }^{33}$ Imprecatory Psalms are abjurations against the evil forces and spirits who are personified as evil men. ${ }^{34}$ Sigmund Mowinckel has a similar belief that imprecation is actually curses that are pronounced against evil and demonic forces "which manifests themselves in illness and all forms of evil." 35

According to Luc, Vos and Day, the imprecatory Psalms, despite the historical context in the Old Testament, are still relevant to the other context and is relevant to Christians because it is an appeal to the justice of God. ${ }^{36}$ Each imprecatory Psalm should be studied in its social and cultural and religious settings to be able to bring out their relevance. For example, the imprecatory

28 Laney, "Imprecatory Psalms", 35.

29 Adamo, "The Imprecatory Psalms in African Context," 139-153.

30 Rudolf Kittel, The Scientific Study of the Old Testament (New York: Putnam, 1910), 143.

31 Peter Craige, Psalms 1-50, 41.

32 Herbert Lockyer, Psalms: A Devotional Commentary (Grand Rapids: Kregel, 1993), 446-447; See also Alec Luc, "Interpreting the Curses in the Psalms," Journal of Evangelical Theological Society 42 (1999): 398; Simango and Kruger, "Study of Imprecatory Psalms," 586,

33 Laney, "Imprecatory Psalm," 42; Allan Harman, "The Continuity of the Covenant Courses in the Imprecations of the Psalter," The Reformed Review 54 (1995): 66-72.

34 Laney, "Imprecatory Psalms," 39.

35 Sigmund Mowinckel, The Psalms in Israel's Worship (Oxford: Blackwell, 1962), 48-49.

36 Simango and Kruger, "Study of Imprecatory Psalms," 592; Geerhardus Vos, "The Ethical Problem of the Imprecatory Psalms," 136; Day, The imprecatory Psalm and Christian Ethics, 171-168. To Yahwesize means to do it in the name of Yahweh. 
Psalms are within the framework of the practice in ancient Near East. What appears distinctive in the imprecatory Psalms is that the author of imprecatory Psalms Yahwesized them. ${ }^{37}$

Psalm 35 is "a characteristic prayer of lamentation" which "consists of three recurring speech patterns of Israel's lament" 38 It is commonly considered as an individual lament or a prayer or royal Psalms. "Recent study of the Lament Psalm or an individual Laments has indicated their enormous theological significance in the faith and Liturgy of ancient Israel and in their subsequent use by the church. ${ }^{40}$

Psalm 35 makes significant use of repetition which can serve as an illustration of the uses of the technique in the entire Psalms. ${ }^{41}$ These repetitions occur in the first verse. There are repetitions that appear close to each other with no more than a sentence apart. According to Segal, these repetitions, in order of their first appearance are: "contend," "fight," "Lord's angel.," "without reason," "hid," "net," "calamity, "the poor," "reply-repay," "gather," "lurking," "smirking..." "speak," "aha," "seen," "my cause," "exalt" "frustration," "desire," and "righteousness." 42 These terms are for emphasis.

Some repetitive terms appear further apart from each other in the chapter. Examples of such terms are "contend" $(1,23)$, "pursue," $(3,6)$, "deliverance" $(3$, 9), "frustrated" $(4,26)$, shame," $(4,26)$, “disgrace" $(4,26)$, "rise" $(2,11)$, "without reason," (7,7), "dug" (7), "unaware" $(8,11,15)$, "say" $(3,10,21,25$, 25, 27), "praise," 18, 28), "well-being,"43

The term like "My soul," appear about 7 times in about 8 variations. ${ }^{44}$ There are two "turn of phrases," in verse 25. It looks like the use of the singular (heart, soul) appears ironic reflection on the enemies' self-proclaimed unity or a direct reflection of the single-mindedness of their evil." "45 A play on words (soul) also appears which can also mean "throat." It can be paralleled to the celebration, "We have swallowed him." 46

\footnotetext{
37 Simango and Kruger, "Study of Imprecatory Psalms," 584.

38 Brueggemann \& Bellinger, Psalms, 174.

39 Craigie, Psalms 1-50, 285.

40 Walter Brueggemann, The Psalms and the Life of faith (Minneapolis: Fortress Press, 1995), 98.

41 Benjamin J. Segal, A New Psalm (Jerusalem: Green Publishing House, 2013), 161.

42 Segal, A New Psalm, 161.

43 Ibid., 161.

44 Ibid., 162.

45 Ibid., 162.

46 Ibid., 162.
} 
The language of war and jungle is a regressive language proving that things have gone out of control but not hopeless because such language drives one from self-reliance to Yahweh. ${ }^{47}$ Psalm 35 and its urgency include such a description of enemy that has not been seen in the other Psalms (e.g. 4 and 6). The enemy has not spoken any peace and they are described so that God will know how terrible they are so that justice is done. That is the reason for spitting so much venom. There is evidence for indignation and the speaker asks questions, where are you, God? How long will it take before you do what is expected of you?

The Promise of praise in vs. 10 asserts the distinctiveness of God, that is, when Yahweh delivers the poor and the wretched one, it will then be known that there is none but him (cf. 9). True deliverance comes from Yahweh. The question, what kind of God will you be if you do not deliver? God's incomparability is closely linked with his deliverance of the helpless and the poor. According to Brueggemann, there is a "dynamic intentionality" in this Psalms in which the God-question is not settled yet and therefore, being worked out with God. ${ }^{48}$ The Psalmist in verse 24 asks God to vindicate him according to his righteousness (צדק).

Verses 1-3 begin abruptly with a barrage of military imagery as God is called upon to fight and battle on the Psalmist's behalf. God is asked to get all the military weapons to war. Verse 14 shows that the enemies to fight are not foreign enemies. In verses 1-3 the petition to Yahweh is strong. It seems as if the Psalmist is saying, after all, the trouble is yours, God and it is time to act and fix it. In verse 17 the language is changed from the military language to that of the jungle still with the purpose of telling Yahweh to act.

The hymnic portion of the praise is called, "praise anticipating response," has two important declarations: the incomparability of Yahweh who rescues the lowly and the needy and the declaration of Yahweh's greatness whose pleasure is to bring peace (שלם) for his servant. ${ }^{49}$

There is a promise of praise in verse 18 and 27

I will thank thee...

I will praise thee...18

Great is the Lord...27

\footnotetext{
47 Brueggemann, The Message of the Psalms, 64.

48 Ibid., 66.

49 Mays, Psalms, 154-155.
} 
Anticipation of praise in Psalm 35 is noteworthy. They are sure anticipation as if he has done it. They are "withheld anticipations" because the speaker has not engaged it. ${ }^{50}$

Verse 22-24 is an appeal and a request to God to demonstrate his presence because of his righteousness. He should make things right again because the speaker cannot control the situation anymore.

The wish that every thinkable and unthinkable trouble should come on his enemies $(7,15-16,20-21)$ is very strong. This continues in 19, 25, and 26. In verse 27-28 the formula is "Let those who desire my vindication shout for joy...my tongue shall tell of thy righteousness"- (צדק). When one reflects on the mood and movement of this psalmist prayer one will notice that the prayer life of the speaker is filled with anger and indignation and rawness without any little attempt to be polite or docile; no cover-up and real prayer about negativities are open up; his relationship to God is not comfortable or congenial. ${ }^{51}$ In other words, unless God delivers he will not be distinctive. The distinctive feature of Psalm 35 that sets it apart from other books of the OT, especially, the entire Psalms, is that it contains the words of human being addressing God rather than the words of God spoken to human. ${ }^{52}$ The Psalmist identifies his personal enemies with those of Yahweh and believes in divine justice. ${ }^{53}$

\section{AFRICENTRIC READING OF PSALM 35}

Unlike some Western scholars who see Psalm 35 as a difficult Psalm because it is full of curses, violence, vengeance and therefore, unfit for Christian Bible, most Yoruba scholars and Christians consider this Psalm as a psalm of protection, defence, and liberation or victory over enemies. It is also considered as a therapeutic and success Psalm. However, it is important to discuss the concept of enemies in Yoruba religious tradition before discussing Psalm 35 in Yoruba Christianity since this interpretation is closely tied with Yoruba indigenous religion and tradition. An example of such African indigenous prayer is below:

...Od'oluworo-ji-woro It becomes oluworo ji-woro

Ki awonota mi lo gbere $\quad$ So let my enemies be lost forever

Oku ajaniwon They are dead dogs

50 Brueggemann, The Message of the Psalms, 65.

51 Ibid., 66.

52 Nancy L. deClaisse-Walford, "The theology of the Imprecatory Psalms," in Sounding in the Theology of Psalms, Perspective and Method in Contemporary Scholarship (ed. Rolf A Jacobson; Minneapolis: Fortress Press, 2011), 78.

53 Crenshaw, The Psalms, 65-71. 
944 Adamo, "Psalm 35 in Africa Perspective," OTE32/3 (2019): 936-955

Oku agboniwon

Ewe gbigbeniwaon
They are dead rams

They are dried leaves (Adamo 2001:69).

The words of Psalm 35 closely resemble Yoruba indigenous prayers and indigenous tradition and saying Orisati ko gbeni, a kiibo- the god that does not deliver should not be worshipped. ${ }^{54}$

\section{Enemies in Yoruba Indigenous Tradition}

The nature and process of dealing with enemies in African indigenous tradition are remarkably different from that of the Western world because Africans who live in the continent face some peculiar problems. To them, nothing happens without a cause. All evil things happen as a result of an enemy's activity.

The existence of enemies is real to indigenous Africans, especially the Yoruba people of Nigeria.55 To them, everybody has an enemy, real or unreal. The presence of evil, witches, sorcerers, evil spirits, and all kinds of enemies is painfully real.56In the African religious experience, everyone is made aware of the need to be protected against enemies. There are two main types of enemies that are greatly feared among the Yoruba people. They are orogun and aye. Orogun are enemies that come as a result of having many wives and power dispute from chieftaincy titles or land ownership. Aye literally means "world." It refers to witches, sorcerers, the underworld people or all people who operate secretly with an evil intention that are not really seen with our naked eyes and refers to witches, sorcerers, the underworld people or all people who operate secretly with an evil intention that are not really seen with our naked eyes.57 An enemy in the Yoruba understanding may include opposition from individuals and organized opposition from both human and spiritual groups working together. The definition of who is an enemy includes, personal and close friends. Enmity may also occur as a result of a quarrel between two persons who refuse to forgive

54 The story behind this Yoruba saying comes from the experiences of the Yoruba indigenous people whose children were sick and they cried to their gods (orisa) to deliver the children, but the children eventually died. The common reaction to these bitter experiences was to abandon the family gods who refused to perform or deliver their children from death. In practice, they looked for a more powerful god who could deliver them and their children.

55 Adamo, "Reading Psalm 109," 575-592.

56 Ibid., 575-592.

57 P. A. Dopamu, "The Reality of Isaasi, Apeta, Ironsi and Efun as forces of Evil as Forces of Among the Yoruba," Journal of Arabic and Religious Studies 4 (1987): 5061; David T. Adamo, Biblical Interpretation in African Context, 139-153; Sola Ademiluka, "The Therapeutic Psalms: Inculturating Christianity in Africa," African Ecclesiastical Review 37/4 (1995): 221-227. 
each other.58 They may include all oppressors, the so-called friends and of course, the devils and demons.

There are three ways of dealing with one's enemies according to the Yoruba expression, namely; (1) the use of incantation or potent words or ofo,ogede or madarikan in Yoruba words; (2) medicine called tira or talisman; (3) herbs or lotions. The three methods are prepared by priests called babalawo in Yoruba language. ${ }^{59}$ Tira is the writing of certain words (usually negative) in parchments which are then put in the pocket or worn on the body for protection against enemies. Another formula of applying the Tira is tying it to the doorpost. Application of the treatment includes drinking of herbs and applying lotion to one's body to prevent any harm.

Right from time immemorial indigenous African/Yoruba people had the belief that words are powerful and can hurt or destroy the person to whom the words are directed. Words are believed to have "effectuating power."60

The method that appears to be the most popular is ogede, ofo or potent words. Ofo is based on a powerful belief in the power of the spoken words. This is why it is called ofowhich literally means "speaking" or incantation. In almost every Yoruba prayer, there is an element of ofo, ogede, ormadarikan, especially in the Pentecostal or Aladura churches. ${ }^{61}$ It is backed up with unflinching faith. The petitions (ebe) of the one uttering the prayer and the one responding (a secompulsory) ${ }^{62}$ are very strong. They have great authority and the conviction that their requests have been granted as requested. ${ }^{63}$ According to Olatunji,

The Yoruba people call all incantations ofo but have other terms which seem to belie the generic value of the term. These other terms include ogede or igede in Oyo area, asapa (that used to kill), atubi (that which unties evil), abilu (that which is pushed against someone), awure (that which brings good luck). ${ }^{64}$

58 Solomon O. Ademiluka, "Identifying the enemies of the Psalmist: From an African Perspective," Theologia Viatorum 33/3 (2009): 216-241.

59 Adamo, "Reading Psalm 109," 575-595.

60 Simango \& Kruger, "Study of Imprecatory Psalms," 584.

61 Ofo is the verbal aspect of magic. This verbal aspect of magic sometimes is called "spell" or incantations (Olatunde O. Olatunji, Features of Yoruba oral Poetry [Ibadan: University Press Limited, 1984],140). Ofo can be accompanied by rites, medicine or charms. The rites, medicine and charms can also be used independently. It can be chanted or recited. It involves the uttering of words according to a set of formula and in a set order. Ofo is "seen as a source of mystical power and the attainment of metaphysical manhood by the Yoruba people. It is a restricted poetic form that is mystical in its expectation, Olatunji, 139. Ofo can be used for good or evil.

${ }_{62}$ Ase as a response to prayer means "it must be so" or "it is compulsory that it is so.

63 Oduyoye, Vocabulary of Yoruba Religious Discourse, 48.

64 Olatunji, Features of Yoruba oral Poetry, 145 
Ayajo is also used to refer to ofo in which mythical allusions are made to ese ifa oracle. ${ }^{65}$ According to Olatunji, "It would be ideal and consistent to refer to all incantations as ofo or ogede no matter their functions. ${ }^{66}$ According to him "the term ogede can be used in the same generic sense as ofo." ${ }^{~}$ Aasan is another term used in the discussions of ofo. It is believed that the words ofo, ase, ogede, madarikan have unfailing effect. The power of such unfailing effect are said to be possessed by medicine men (babalawo), priests, herbalists, aged parents on their death beds. Such powers are irrevocable. ${ }^{68}$

Dopamu and Olatunji mention different kind of incantations as follows:madarikan (back to the sender), ofoawonaje(for preventing witches from hurting a person), ofoowo(incantation to earn respect generally, ofodidaepe pada (sending a curse back to the sender), ofoawise (incantation to make words irrevocable), ofoki a maaku (incantation to prevent death) and ofoasetaa (incantation for victory against enemies). ${ }^{69}$

\section{Examples of $O f o$ for Protection}

Below are examples of some ofo, ogede that are irrevocable when uttered. It is all about the fact that enemies should be scattered and anyone with evil intent should use his or her hand to undo himself or herself. These ofo is for protection.

Itu to niki won o ma tu won $\mathrm{ka} \quad$ It is the he-goat that says they should be scattered

Eni tina n peri mi nibi

Oso ki I roro ko jerun

A ki I fowoobeesebo

A ki I fibo bole

A kiki I fiboseku

Eni ti $n$ ba n peril mi nibi

Funraa won ni o fowoaraa won

65 Ibid., 145.

66 Ibid., 146.

67 Ibid., 145.

68 Oduyoye, Vocabulary of Yoruba Religious Discourse, 48.

69 A. P. Dopamu, Madarikan, OfoIsegun (Ibadan: Sefer, 2000), 1-33; Olatunji, Features of Yoruba oral Poetry, 147.
Whoever has evil designs on me

No wizard can be fierce enough to eat the eran wood

No one spends his food money to cook the ibo plant

No one worships the ground with ibo plant

No one uses the ibo plant in cooking rat

Whoever has evil designs on me

He should with his own hand undo himselfsera 
Aidan lo ni e ma le e fibiowoo yin mi wo

Eerumaarubi won to won
It is the aidon plant (Tetrapleura[Mimosaceaedan [Mimosaceae]) that says he shouldnot try his evil designs on me.

Eeru plant (PachyelasmaTesmannil,Used in smoking away witches), carry his evil Designs to him. $^{70}$

Other examples of other potent words, ofoor ogedeare also cited below with a title, A-sure-pa-ni:

A-sure pa-ni la a pe Ogun

Ogun, sure ba mi pa awonotaa mi

A-fi-irin-gberegberepani la pe a ifa

Ki o lo ba mi pa gbogboawon

otaa mi...

Gbogboawontinmba mi sota,

To ba n fenuburukukan mi,

Ifabami ran won lo si ode orun...
A-sure-pani we call Ogun (Yoruba god of Iron) instant killer.

We call Ogun (Yoruba god of Iron) instant killer We call ifa (Yoruba oracular divination) a killer by walking

Let him go and kill all my enemies

The above ogede, ofoormadarikan is calling the gods of the Yoruba (Ogun and Ifa) to get up and kill all the speakers' enemies instantly just as the psalmist has desired in 35: 1-3 when the psalmist challenged Yahweh to take a shield and buckler, spear, and javelin. Let the angel of Yahweh pursue them and put them to shame.

Another example of ofo, ogedeormadarikan is written below and named Ajan-koro-biti and requesting that enemies should die by crucifixion as Psalm 35 wanted his enemies to die.

Ataponikilagbaja ko talu po oLet so-and-so go out of town

Ko wogbo lo rereere

Igbo rereerenilelagbaja
Let him go deep into the woods

The deep woods is the home for so-and-so 
948 Adamo, "Psalm 35 in Africa Perspective," OTE32/3 (2019): 936-955

Ko ma gbeeaarinilumo

Ko delekiisaa
Let him not live in the community again

Let him become a wearer of rags. ${ }^{72}$

When the aboveofo or incantations is compared with Psalm 35:4-6, the resemblance is clear.

Let them be put to shame and dishonour who seek after my life.

Let them be turned back and confounded who devise evil against me

Let them be like chaff before the wind, with the angel of the LORDdriving them on.

Let their way be dark and slippery, with the angel of the LORD pursuing them(35:4-6 NRSV).

It is important to note that despite the fact that the Yoruba ofo or madarikan, or ogede and Psalm 35 are close in content and intentions, there are some differences. While the addressee of Psalm 35 is God, that of the Yoruba ofo or ogede is to the gods such asEsu, Ogun, Ifa and others rather than the Supreme Being, Olodumare. Both resemble the belief in the power of spoken words.

\section{$3 \quad$ Psalm 35 as Protection and Defence against the Attack of Enemies}

When Christian missionaries arrived in Africa, the converts were forbidden to use African indigenous medicine, that is, powerful potent words, ofo, madarikan, orogede talisman, and even herbal medicine for protection. They were told that it was abominable to Christianity. The missionaries, with good intentions of promoting the kingdom of Christ, did not only build schools, they built maternity buildings and hospitals where orthodox medicine was dispensed. However, those African Christians who had access to orthodox medicine still had problems dealing with what they believed to be the source of the diseases, and misfortune (witches and wizards and other enemies, seen and unseen). They sought protection from the use of the Bible-Psalms texts since orthodox medicine could not deal effectively with that aspect of African belief.

When they accepted Christianity and replaced their potent words, charms, and all kinds of medicine, they did that with the belief that there would be a better substitute for them for protection, healing, and success. Unfortunately, however, they were not taught the source of the white man's power which they believed was in the Bible. Other non-converts ridiculed them and called them "women" because they had no ofo or madarikan or incantation or talisman for protection. They were disappointed, and therefore, took laws into their hands by using the Bible and the traditional means for protection, healing and success. For that reason. Many were excommunicated from the mainline churches. When others who remained in the missionary churches searched in vain for answer they

72 Ibid., 31 
eventually broke away ${ }^{73}$ from the missionary churches with one of the major purpose of finding that greater power in Christianity. They search the Bible in their own ways. The separation gave them more freedom to search the Bible more in order to discover the supposedly hidden power. The book of Psalms became the favourite book that contained that power for protection, and defence against known and unknown enemies. They found the words of Psalms that resemble almost exactly their irrevocable ofo, incantation, ogede or madarikan. They approached the Bible and used it with the same method that the indigenous Yoruba people used for their indigenous medicine, incantation, ofo, madarikan or ogede to deal with the problem of enemies. They used mainly the imprecatory Psalms such as Psalms 35 as they used potent words, charms, and medicine to combat evil forces and to protect themselves against forces of evil. They believe that Psalms like Psalms 35 are irrevocable. It can be read, recited, written in a special paper for protection. They wrote it on their doors, on their bodies, on their clothes for protection with strong faith that it will work. They sang, chanted, and believed that it would work for them. That was how Psalm 35 became a talisman, and a psalm of protection, healing and success in Yoruba Christianity. That is how imprecatory psalms also became somehow popular among African indigenous churches. This practice has spread to most of the mainline churches in Nigeria, especially among the Yoruba people. This was based on the belief in African tradition that words are not just empty thought. They are performative and once words go out with faith they perform the purpose for which they are spoken. Such is the power in the spoken words when they are memorized, spoken, and recited. According to African tradition and religion, they can destroy enemies and evil ones. This belief was also influenced by the word of the Bible especially the book of Psalm with the idea that God created things by spoken words and destroyed things by the breath of his mouth (Psalm 33:6). They read the Bible and believe that the word of God is more powerful than a two-edged sword according to Hebrew 4:12. They believe that the word in the Bible, is the word of God which is

living and active. Sharper than any double-edged sword, it penetrates even to dividing soul and spirit, joint and marrow it judges the thought and active of the heart (NRSV).

The Yoruba Christians maintain their belief that the word of God is more powerful than the African indigenous potent words (ofo or incantations). They use the word of God for protection, for healing and success.

73 There are other important reasons for the emergence of African Indigenous Churches: national feelings, struggles for authority and leadership disagreement over finance, breaches of church discipline, polygamy, lack of adequate attention paid to dreams, prophecy, and healing ministry of both body and soul. 
Some verses of Psalm 35 are written on the doorpost to protect the house; on motor vehicles to prevent enemies from causing accident; and on parchment to ward off evil spirits. Some will also be read into water for healing.

In fact, Psalm 35 is regarded as Madarikan, ofo, orogedein Yoruba tradition. Madarikan is another way for protection in African religion and tradition. Ade Dopamu, an eminent Professor of African indigenous religion believes that Psalm 35 is ofo, madarikan, and ogede. ${ }^{74}$ According to him,

The Yoruba people use Madarikan or ofofor victory over enemies.

One does not wait for the time one is aware that he/she has enemies

before using Madarikan.

Because it gives victory over enemies known or unknown.

Because it gives victory over known and unknown enemies.

Madarikan is not an evil thing because it delivers people from the evil ones. It thwarts the evil plan of enemies to nothing (translation). ${ }^{75}$

Dopamu also compares madarikan with the book of Psalms. According to him,

It is like the psalms that Christians recite in Psalm 35:1, 8:

Contend, O LORD, with those who contend with me;

Fight against those who fight against me...

May ruin overtake them by surprise-

May the net they hid entangle them,

may they fall into the pit, to their ruin (Psalm 35:1,8 NRSV). ${ }^{76}$

Further comparison of the above madarikan with Psalms shows real similarities. ${ }^{77}$

Clement Ekundayo believes that there are Psalms to be recited for victory, mercy, and success. According to him Psalm 35 should be read three times facing the four corners of the earth and certainly, God will wage war against one's enemies. $^{78}$

${ }_{74}$ Dopamu, Madarikan, OfoIsegun, 30.

75 Ibid.

76 The existence of words of hate or harsh words does not mean that the Yoruba or African religion is "inherently violent" and characterised by hate speeches just as the existence of Psalm 35 and other imprecatory Psalms does not mean that Christianity and Judaism are inherently violent and characterised by hate speeches. Such a conclusion will make no sense because it is the way a person practices religion that makes it to be violent and characterised by hate speeches.

77 Dopamu, Modarikan, 30.

78 C. Ekundayo, Lilo Awon Psalmu fun Aseyori, Aanuati Ojurere Olorun, Intercel Christian (Ibadan: Publication, 1996).11. 


\section{CONCLUSION}

The summary of Psalm 35 is that the psalmist confronted his God with the mystery of evil and suffering in the world of oppression, hatred, poverty, violence in the unjust world, and asks God to take action immediately.

The temptation is to condemn Africentric approach to Psalm 35 as magical, fetish, syncretistic and therefore unchristian. However, a closer examination of this method proves otherwise. Such use reveals the strong belief in the power of God's name. It is a demonstration of the power in the words of God more than the Yoruba culture and tradition. The word of God is sharper than a two-edged sword (Heb12:4). The Yoruba people use Psalm 35 not for an aesthetic purpose but to express God's righteous indignation against injustice and evil.

Praying Psalm 35 is an act of faith that God will judge the wicked and therefore, instead of fighting by visiting babalawo (Yoruba medicine man) to obtain medicine to kill the enemies as it is often the case, in African Indigenous religion. The Yoruba Christians leave everything to God to do justice for the oppressed. ${ }^{79}$

Furthermore, reading Psalm 35 in African Context has several advantages. It has the economic advantage because the reader will not have to visit the native priest (babalawo) with fees, for incantations and medicine to fight the enemies. The reader has a substitute for incantations free of charge, which is more powerful than ofo. Reading Psalm 35 relieves him of her psychologically from being called a woman (if he is a male). The fact that reading Psalm 35 works gave her courage and faith in God and his words (Bible)...

Both Psalm 35 and ofo or madarikan also remind us of the basic human desire for revenge when hurt by enemies. God does not ask us to suppress the anger, but instead, to give that anger, the hopelessness, and the pain a voice. "Submission of anger to God obviates the need for actual revenge of the enemy" ${ }^{80}$ For survivors of victimization, "to express grief and rage and outrage is to live, to remember is to bear the pain of reliving an unutterable horror... But to remember is also to resist the forces of evil in the hope of livingresurrection." 81

Among the many reasons why Psalm 35 is read Afrocentrically, is that the method did not only worked for the early Yoruba indigenous Christians who

\footnotetext{
79 Adamo, "The Imprecatory Psalms in African Context," 151.

80 J. Clinton McCann Jr., A Theological Introduction to the Book of Psalms (Nashville: Abingdon Press, 1993), 119.

81 McCann, Theological Introduction, 19.
} 
used it that way, ${ }^{82}$ it may likely be the way Psalm 35 was used in ancient Israel, that is, for protection, healing and success. ${ }^{83}$

The Yoruba Christians read, sang, recounted, chanted, and inscribed Psalm 35 with a view not only to be protected on such a dangerous journey on the African roads or on a flight or sea in the continent, but also in order to testify to Israel's "originary event and its enduring generative power." ${ }^{\text {" }}$. The Psalmist in $35: 9,10,18,27$ and 28 in my view, recounts Israel's history in praise and thanksgiving as a way of expressing their belief in God's continuing historical involvement. By evoking the past, through proclamation, singing/chanting, writing and reading, the ongoing nature of the relationship which God has begun with God's people is expected to be renewed and continued. ${ }^{85}$ In other words, the author of Psalms 35 wrote for the purpose of not only expressing God's action in history but also for the transformation of those who read the Psalms. This is the recounting of God's power. Westermann calls such praises and allusions in Psalm "Representation of History" which allows Israel/ African Christians their covenant relationship with God. ${ }^{86}$

Yoruba people believe that those who recount Palm 35, and of course, some other specific Psalms, by writing, singing, chanting, and wearing the words of this Psalms on their bodies take up the identity of ancient Israel who was the first receiver of God's miracles and actions. This brings out the possibility of their receiving the same miraculous action of God in history. ${ }^{87}$

82 Adamo, "Reading Psalm 109," 575-592; Caleb O. Ogunkunle, 'Imprecatory Psalms: Their Forms and Uses in Ancient Israel and some Selected Churches in Nigeria,' (Ph.D Dissertation: University of Ibadan, Nigeria, 2000), 217; J. O. Oshitelu, The Secret of Meditation with God with the Uses of Psalms (Shagamu: Publication Department, the Church of the Lord Aladura Worldwide, Shagamu, n.d).

83 The discovery of a handful of Phoenician and Punic amulets from the first millennium with two verbs (שמר guard and נצר protect) inscribed on them is an indication that such practice was uncommon in ancient Near East generally. David T. Adamo, "The Significance of Psalm 121 in African Context," Journal for Semitics, 26/1 (2017) 33-44; Philip C. Schmitz, "Reconsidering Phoenician Inscribed Amulet from the Vicinity of Tyre," Journal of the American Oriental Society 122 (2002): 817-22; Jeremy D. Smoak, "Amuletic Inscriptions and the Background of YHWH as Guardian and Protector in Psalm 12," Vetus Testamentum 60 (2010): 421-432; "Prayers of Petition in the Psalms and West Semitic Inscribed Amulets: Efficacious Words in Metal and Prayers for Protection in Biblical Literature," Journal for the Study of Old Testament, 36/1 (2011): 75-92.

84 Brueggemann, Psalms and the Life of faith, 34.

85 Harry P. Nasuti, "Historical Narrative and Identity in the Psalms," Horizon in Biblical Theology, 23/2 (2001): 132-153.

86 Claus Westermann Praise and Lament in Psalms (trans. Keith R. Criand, Richard N Soulen; Atlanta: John Knox Press, 1981), 214-249.

87 Nasuti, "Historical Narrative and Identity in the Psalms," 132-152. 
One will be right to say that the Psalms became the means by which Yoruba/African Christians experienced the repetition of their origin in God. It is a re-experience of the salvation history.

The writing, chanting, singing of Psalms 35 repeatedly is for the purpose of reminding God of his former actions and to motivate God to act in this way once again in the present. ${ }^{88}$

The Bible, particularly the Psalms, then becomes a substitute for talisman or amulets, medicine, potent words (so-called incantation), ofo, madarikan, ogede for protection, healing, and success when inscribed on parchments, bodies, vehicles, doorposts, recited, chanted, and sung with unwavering faith or trust in God. What I think should be noticed is that the Yoruba Christians believe that if the gods of the Yorubas are so powerful as to punish at will when requested, how much more Yahweh, the God of Israel, the God of the missionaries for whose purpose they left their countries to go to Africa? The conclusion is that the Christian God and his words must be more powerful and distinct.

\section{BIBLIOGRAPHY}

Adamo, David T. "Reading Psalm 23 in African context," Verbum et Ecclesia 39(1), a1783, 2018, 1-8.https://doi.org/10.4102/ve.v39i1.1783.

. "The Task and Distinctiveness of African Biblical Hermeneutic(s)," Old Testament Essays, 28/1 (2015), 31-52. https://doi.org/10.17159/2312-3621/20 $15 / \mathrm{v} 28 \mathrm{n} 1 \mathrm{a} 4$.

. What is African Biblical Hermeneutics?" Journal of Black Theology, vol. 13 no 1, 2015; . "Reading Psalm 109 in African Christianity," Old Testament Essays 21/3, 575595.

. "The Imprecatory Psalms in African Context. "D.T Adamo (end), Biblical Interpretation in African Perspective, Lanham: University of America, 2006), 139-153.

. Reading and Interpreting the Bible in African Indigenous Churches Eugene, Oregon: WIPF and Stock Publishers, 2001.

Ademiluka, Solomon O. "Identifying the enemies of the Psalmist: From an African Perspective," Theologia Viatorum, 33, 3 (2009), 216-241.

"The Therapeutic Psalms Inculturating Christianity in Africa," African Ecclesiastical Review 37, 4 (1995),221227.

Brueggemann, Walter. The Message of the Psalms: A Theological Commentary. Minneapolis: Augsburg, 1984.

The Psalms and the Life of faith. Minneapolis: Fortress Press, 1995.

Brueggemann Walter and William H. Bellinger Jr. Psalms, Cambridge: Cambridge University Press, 2014.

Craigie, Peter C, Psalms 1-50. Waco: Word Publisher, 1983.

Crenshaw, James L. The Psalms: An Introduction, Grand Rapids: William B Eerdmans, 2001.

88 Westermann, Praise and Lament in Psalms, 217. 
Day, John N. “The Imprecatory Psalms and Christian Ethics.” Bibliotheca Sacra 159 2002): 166-185

deClaisse-Walford, Nancy L. Introduction to the Psalms, Chalice Press, St. Louis, 2004.

deClaisse-Walford, Nancy L. "The Theology of the Imprecatory Psalms." Pages 77-92 in Sounding in the Theology of Psalms, Perspective and Method in Contemporary Scholarship. Edited by Rolf A. Jacobson. Minneapolis: Fortress Press, 2011.

deClaisse-Walford, Nancy L., Rolf A. Jacobson, and Beth A. Tanner. The Book of Psalms, Grand Rapids: William B. Eerdmans Publishing Company, 2014.

Dopamu, A. P. Madarikan, OfoIsegun. Ibadan: Sefer, 2000. . "The Reality of Isaasi, Apeta, Ironsi and Efun as forces of Evil among the Yoruba." Journal of Arabic and Religious Studies 4 (1987): 50-61.

Ekundayo, C. Lilo AwonPsalmu fun Aseyori, Aanuati Ojurere Olorun, Ibadan: Intercel Christian Publication, 1996.

Getui, Mary N., Knut Holter and Victor Zinkuratire (eds), Interpreting the Old Testament in Africa. New York: Peter Lang, 2001. https://doi.org/10.3726/9781-4539-1010-8.

Harman, Allan. "The Continuity of the Covenant Courses in the Imprecations of the Psalter." The Reformed Review 54 (1995): 66-72.

Holter, Knut. Contextualized Old Testament Scholarship in Africa. Nairobi: Acton Publisher, 2008.

Interpreting Classical Religious Texts in Contemporary Africa. Nairobi: Acton Press, 2007.

Kittel, Rudolf. The Scientific Study of the Old Testament. New York: Putnam, 1913.

Kraus, Hans-Joachim. Psalms 60-150. Translated by H. C. Oswald. Minneapolis: Augsburg, 1988.

Laney, J. Carl, A Fresh Look at the Imprecatory Psalms," Bibliotheca Sacra, 159 (1981):35-44.

Lockyer, Herbert. Psalms: A Devotional Commentary. Grand Rapids: Kregel, 1993.

Luc, Alec. "Interpreting the Curses in the Psalms." Journal of Evangelical Theological Society 42 (1999): 395-410.

Martins, Chalmers. "Imprecatory in the Psalms." Pages 113-132 in Classical Evangelical Essays in Old Testament Interpretation. Edited by W. Kaiser. Grand Rapids: Baker, 1972.

Mays, James L. Psalms. Interpretation. Louisville: Westminster/John Knox Press, 1994.

McCann, J. Clinton Jr. A Theological Introduction to the Book of Psalms, Nashville: Abingdon Press, 1993.

Nasuti, N. P. "Historical Narrative and Identity in the Psalms." Horizon in Biblical Theology, 23/2 (2001): 132-153.https://doi.org/10.1163/187122001x00071.

Mowinckel, Sigmund. The Psalms in Israel's Worship. Oxford: Blackwell, 1962.

Oduyoye, Modupe. Psalms without the Curse Words. Ibadan: Sefer Press, 1997.

Ogunkunle, C. "Imprecatory Psalms: Their Forms and Uses in Ancient Israel and some Selected Churches in Nigeria," A Ph.D Thesis, University of Ibadan, Nigeria, 2000.

Okorocha, Cyril. "Psalms." Pages 605-746 in Africa Bible Commentary. Edited by Tokunbo Adeyemo. Nairobi: Word Alive Publishers, 2006. 
Olatunji, O. Features of Yoruba oral Poetry. Ibadan: University Press Limited, 1984.

Oshitelu, J. O. The Secret of Meditation with God with the Uses of Psalms. Shagamu: Publication Department, the Church of the Lord Aladura Worldwide, n.d.

Peels, Hendricks. Shadow Sides: The Revelation of God in the Old Testament. Carlisle: Paternoster, 2003.

Ross, Allen P. A Commentary on the Psalms Volume 1 (1-41). Grand Rapids: Kregel Academic, 2011.

Schaefer, Konrad. Psalms. Collegeville: The Liturgical Press, 2001.

Segal, Benjamin J. A New Psalm. Jerusalem: Green Publishing House, 2013.

Simango, Daniel and Paul Kruger. "An Overview of the Study of Imprecatory Psalms: Reformedand Evangelical Approaches to the Interpretation of Imprecatory Psalms." Old Testament Essays 29/3 (2016) 581-600. https://doi.org/10. 17159/2312-3621/2016/v29n3a13.

Smoak, Jeremy D. "Amuletic Inscriptions and the Background of YHWH as Guardian and Protector in Psalm 12." VetusTestamentum 60 (2010): 421-432. https://doi.org/10.1163/156853310x504856.

. "Prayers of Petition in the Psalms and West Semitic Inscribed Amulets: Efficacious Words in Metal and Prayers for Protection in Biblical Literature." Journal for the Study of the Old Testament, 36/1 (2011): 75-92. https://doi. org/10.1177\%2F0309089211419419.

Ugwueye, L. E and Uzuegbunam, E. N. "An Appraisal of the Use of Psalm 35 as 'Dangerous Prayer' in Mountain of Fire and Miracle (MFM) Church." African Research Review 7/1 (2012): 14-33. https://doi.org/10.4314/afrrev.v7i1.2.

Vos, Geehardus. "The Ethical Problem of the Imprecatory Psalms." Westminster Theological Journal 4 (1942): 123-138.

Wendland, Ernst R. Analyzing the Psalms. Dallas: SIL International, 1998.

Weiser, Artur. The Psalms. Philadelphia: The Westminster Press, 1998.

Westermann. Claus. Praise and Lament in Psalms. Atlanta: John Knox Press, 1981.

Zenger, Erich. A God of Vengeance? Understanding the Psalms of Divine Wrath. Translated by L. M. Maloney. Louiseville: Westminster John Knox Press, 1996.

The Rev Prof David Tuesday Adamo, Department of Religious Studies, KogiState University, Anyigba, Nigeria, Email- adamodt@yahoo.com; ORCID: https://orcid.org/0000-0001-8610-4289. 